\title{
Ensuring Sustainable Development Of Aquaculture By Enhancing The Natural Immunity Of Fish
}

\author{
Tatiana Bikezina, Xiangli Dong, Evgeny Istomin, Yaroslav Petrov*, and Mikhail Shilin \\ Russian State Hydrometeorological University, 79 Voronezhskaya Street, St. Petersburg 192007, \\ Russian Federation
}

\begin{abstract}
One of the main tasks in the coming years will be the development and introduction of vaccines for the development of immunity against intracellular bacterial and viral pathogens. DNA vaccines will play an important role in such cases. With the emergence of intensive industrial fish farms, there were also problems associated with infectious diseases of cultivated objects. These diseases cause significant harm to fisheries and the aquaculture sector of the global economy as a whole. The article shows the way of the development of the environmentally safe and sustainable marine and freshwater aquaculture with using Pisces vaccination, and reveals the role of Pisces aquaculture as an integral part of the world economy, in the face of increasing anthropogenic pressure on aquatic ecosystems and of distribution of new dangerous Pisces infections. Perspective types of Pisces vaccines are presented and discussed. The effectiveness of different types of elaborated vaccines is discussed.
\end{abstract}

\section{Introduction}

In the context of the dramatically growing anthropogenic load on aquatic ecosystems, decreasing of marine and freshwater natural resources of commercial fish species, the role of innovative and environmentally safe aquaculture (including Pisces -culture) as an integral part of the world economy is becoming more and more important. Traditionally, the role of aquaculture is large and constantly growing in countries that have a sufficient supply of marine and freshwater reservoirs and aquatic ecosystems suitable for its development, such as Russia and China. Up to $80 \%$ of world aquaculture production is currently provided by the countries of Eurasia, led by the «big ten» - Vietnam, India, Indonesia, China, Korea, Russia, Thailand, Taiwan, the Philippines and Japan [1]. To the popular objects of modern aquaculture belong such groups of hydrobionts like Algae, Sponges, Corals, Mollusks, Crustacean etc. At the same time, marine and freshwater Pisces species remain the main objects of commercially successful aquaculture.

\footnotetext{
* Corresponding author: yaroslav.petrov025@gmail.com
} 


\section{Problem statement}

With the emergence of intensive industrial marine (in coastal and open waters) and freshwater Pisces-culture farms, acute problems also appeared associated and connected with virus and bacterial infections of cultivated objects. Such illnesses cause significant harm to Pisces-culture, and exert influence on the resulting commercial success of aquaculture business. These diseases cause significant harm to industrial Pisces-culture, and the aquaculture sector of the economy of coastal countries like Russia and China as a whole [1].

For the successful fight against various pathogens, the newly developed drugs with a powerful antibacterial effect are currently widely used, especially in «bir ten» countries. However, their gradual accumulation in the aquatic environment (both in water column and in the bottom sediments) and in cultivated objects (in the biomass of fish) harms the world ecology and human health when eating fish products oversaturated with antibiotics.

\section{Research questions}

To minimize the possible prognosed risks for cultivated objects, marine / freshwater environment, and the human health, the development of environmentally friendly technologies is proposed by professionals, with using the vaccination of cultivated objects and increasing their natural immunity. This, in turn, requires expanding our understanding of the fundamental regularities of the antibacterial Pisces immunity /cultivated species.

To these fundamentals belongs the study of the anti-inflammatory proteins of the fish's immune mechanism. Because of the low level of our present understanding of the role of these proteins in the immune mechanism of Pisces-culture species, studies of the illness model, and regularities of immune response with infections typical of aquaculture objects are first of the planned initial steps in the process of the development of new approaches to their treatment and prevention. Such proteins are, in our study, chemokines (CCL) and mannose receptors (MRC). These proteins play central roles in the Pisces organism and perform key functions: from binding pathogens to cellular signaling in various proinflammatory processes $[2,3]$.

Advance vaccination seems to be an optimal technique to start the development of one of the most important and probably priority approaches to prevent and to control Pisces diseases. Professionals came to the conclusion, that treatment of large spector of bacterial infections of Pisces with exclusively anti-microbial drugs (antibiotics) in the future becomes impossible due to their negative impact on the aquatic environment, cultivated hydrobionts and the human health of consumers of the final production [4].

Recently, we already can observe the significant progress in the Pisces vaccination. Researchers successfully created technics for single immunization of large-scale volumes of planting material and introduced effective methods to the creation of multivalent Pisces vaccines [5].

Vaccination is now successfully used over the world in almost all livestock and aquaculture Pisces species. In aquaculture, the innovative vaccination reduces the routine «normal» using of antibiotics, and at the same time in parallel protects cultured objects from infections. It also avoids the risk of the development and distribution the possible drug resistance. In this direction, the herd level protection can be achieved as a result of herd immunity. At the same time, the formal licensing and official registration of a new vaccines is expected to take less time than in the case of elaboration of new antibiotics [6]. 


\section{Purpose of the fulfilled study}

Managers have different important points to consider before applying vaccination: biological species characteristics of cultured objects; the real status of the immune system of objects of cultivation; the production cycle and life cycle of the cultivated species on the fish farm; features of the seasonal diseases in a fish hatchery; technology of fish farming processes; abiotic characteristics of the aquatic environment (distribution and fluctuation of temperature, salinity, etc.); stressing factors; feeding / nutritional characteristics and monetary benefits [7].

Today, modern vaccines are not enough effective and do not completely prevent the possible disease. The vaccines' antigens are so weak, that they in fact cannot induce sustained immunity in the recipient. Because of that, new strategies should be developed to create principally new effective types of Pisces vaccines [8].

\section{Research methods and techniques}

One of the main aquaculture tasks in the future years will be the elaboration, broad distribution and effective introduction of vaccines for the increasing of Pisces immunity against intracellular micro-biotic pathogens. DNA vaccines should have an important role in these cases.

The whole pool of modern vaccines is classified into «killed», «attenuated», «DNA vaccines», «synthetic peptides», «recombinant vector», «genetically modified» and «subunit vaccines».

«Killed vaccines» are the most commonly used commercial preparations today, produced by destroying the infectious agent, then using it to induce an immune response as an antigen. The effectiveness of these vaccines is based on the easily development, store stable, and relatively inexpensiveness. They are safe due to the practical absence of virulence problems. This type of vaccine is especially effective when we need the prevention of viral hematopoietic necrosis infection [9].

«Attenuated» («live») vaccines» are common vaccines that are used in fish foods to prevent possible diseases [10]. The technology of their production is aimed at the physical and chemical weakening of organisms up to the loss of their virulence, without killing them. Laboratory studies have shown the effectiveness of «live vaccines» in Pisces. The attenuated organism replicates in the target host without any clinical signs, however, it induces the development of cellular and humoral immunity.

«DNA vaccines» are an absolutely new type of Pisces vaccine, produced as effect of advances in molecular biology. To produce the «DNA vaccine», experts don't need to use a pathogen, but only to receive a gene that encodes the antigen of the pathogenic organism, which forms the basis of the vaccine [11].

The advantage of a «DNA-vaccine» is that it is based on purified plasmid DNA that carries only one or a few genes of the pathogen, which makes it unable to reproduce in the host's body and does not carry the risk of transmitting a real disease through the vaccine. This is why «DNA- vaccines» are considered safer than conventional vaccines, that is, inactivating the entire virus, with or without oil adjuvant, or an attenuated live virus.

These vaccines are free of side effects after vaccination. In addition, all of these «DNAvaccines» do not contain the unknown contaminants commonly found in whole body vaccines.

The «DNA vaccines» were used effectively in the vaccination of aquacultural Pisces species like salmon («losos») against infectious hematopoietic necrosis virus and hemorrhagic septicemia virus. The «DNA-vaccines» have also been tested to prevent the spring viremia of carp virus. 
After confirming the effectiveness of the «DNA-vaccines» developed for the treatment of viral Pisces diseases, attempts were made to receive the «DNA-vaccine» as a prophylactic agent against the bacterium Renibacterium salmoninarum, which causes kidney disease in salmon («losos»). However, the elaborated vaccine of this type has not been found to be enough effective at the present time [12].

«Recombinant vector vaccines» are the product of biotechnological progress. «Recombinant vector vaccines» are produced by using only immunogenic regions of a pathogen and expressing it in a heterologous host. Proteins, which are the important immunogenic part of a pathogenic organism, are produced in large quantities outside the body, and only then purified for practical use as a vaccine. When selecting a vector, first of all, such factors as the possibility of producing protein in large quantities and the efficiency of expression of the antigen protein are taken into account. Viruses causing Pisces infectious anemia or hepatopoietic necrosis have been expressed in vectors as a vaccine to protect aquaculture Salmonidae like «losos», «gorbusha» etc. [13].

«Subunit vaccines». If there are difficulties in the cultivation of a pathogenic organism, only its immunogenic part is produced, which is then used as a vaccine. Subunit vaccines are safe to use, but their immunogenic nature is very weak compared to vaccines based on an inactivated pathogen. Therefore, adjuvants are needed to increase immunogenicity [13].

«Genetically modified vaccines». Passing organisms in vitro leads to the accumulation of gene mutations that cause weakening of the pathogen. Microorganisms can be genetically weakened by molecular approaches that involve removing genes responsible for their pathogenicity. The live attenuated vaccine will multiply to a lower titer and may stimulate and increase both humoral and cellular immunity. A genetically modified vaccine against Aeromonas salmonicida has now found its application as one of the means of preventing the salmon aeromonosis [14].

«Synthetic peptide vaccines». These types of vaccines are made from short sequences of synthetic amino acids as antigens [15]. Studies have shown that the Pisces vaccination with peptides is less practical due to the lack of a specific immune response of fish to various antigens and is not strong enough and therefore requires a carrier molecule. Similar vaccines have been tested for the prevention of Pisces infectious diseases such as nodavirus, viral hemorrhagic septicemia, rhabdovirus and birnavirus.

\section{Conclusion}

To date, many commercially available Pisces vaccines have been approved for use in aquaculture worldwide (Table 1).

Table 1. Commercial vaccines - comparative overview

\begin{tabular}{|l|l|c|c|c|}
\hline \multicolumn{1}{|c|}{ Vaccine‘s name } & $\begin{array}{c}\text { Aquatic species to be } \\
\text { vaccinated }\end{array}$ & $\begin{array}{c}\text { Preventioned diseases } \\
\text { 1. }\end{array}$ & $\begin{array}{c}\text { Reference to } \\
\text { literature }\end{array}$ \\
\hline 2. & $\begin{array}{l}\text { Arthrobacter Vaccine Salmonids } \\
\text { Columnaris disease }\end{array}$ & $\begin{array}{c}\text { Salmon («losos») } \\
\text { Salmo salar }\end{array}$ & Furunculosis & {$[16]$} \\
\hline 3. & Vibrio Anguillarum-Ordalii & $\begin{array}{l}\text { Salmon } \\
\text { S. salar }\end{array}$ & Columnariosis & {$[17]$} \\
\hline 4. & Infectious Salmon Anemia Vaccine & $\begin{array}{l}\text { Salmon } \\
\text { S. salar }\end{array}$ & $\begin{array}{l}\text { Salmon } \\
\text { S. salar }\end{array}$ & Salmon infectionis \\
anemia & {$[18]$} \\
\hline 5. & Yersinia Ruckeri Bacterin & $\begin{array}{l}\text { Salmon } \\
\text { S. salar }\end{array}$ & Yersiniosis & {$[20]$} \\
\hline
\end{tabular}




\begin{tabular}{|c|c|c|c|c|}
\hline 6. & $\begin{array}{l}\text { Infectious Hematopoietic Necrosis } \\
\text { Virus Vaccine }\end{array}$ & $\begin{array}{l}\text { Salmon } \\
\text { S. salar }\end{array}$ & $\begin{array}{l}\text { Infectious necrosis of } \\
\text { hematopoietic tissue }\end{array}$ & {$[21]$} \\
\hline 7. & Edwardsiella Ictalurii Vaccine & $\begin{array}{c}\text { Catfish } \\
\text { Ictalurus punctatus }\end{array}$ & Edwardsiellosis & {$[22]$} \\
\hline 8. & $\begin{array}{l}\text { Flavobacterium Columnare } \\
\text { Vaccine }\end{array}$ & $\begin{array}{l}\text { Catfish } \\
\text { I. punctatus }\end{array}$ & Columnariosis & {$[23]$} \\
\hline 9. & Vibrio anguillarum-Ordalii & $\begin{array}{c}\text { Rainbow trout } \\
\text { («forel») Oncorhynchus } \\
\text { mykiss }\end{array}$ & Vibriosis & {$[23]$} \\
\hline 10. & Vibrio salmonicida Bacterin & $\begin{array}{l}\text { Salmon } \\
\text { S. salar }\end{array}$ & Vibriosis & {$[24]$} \\
\hline 11. & $\begin{array}{l}\text { Vibrio anguillarum-salmonicida } \\
\text { Bacterin }\end{array}$ & $\begin{array}{l}\text { Salmon } \\
\text { S.salar }\end{array}$ & Vibriosis & {$[24]$} \\
\hline 12. & Edwardsiella ictaluri Bacterin & $\begin{array}{l}\text { Catfish } \\
\text { I. punctatus }\end{array}$ & Intestinal septicemia & {$[25]$} \\
\hline 13. & Spring viremia of carp virus & $\begin{array}{l}\text { Common carp } \\
\text { Cyprinus carpio }\end{array}$ & Spring viremia of carp & {$[26]$} \\
\hline 14. & Koi herpes virus (KHV) & $\begin{array}{c}\text { Koi carp } \\
\text { C. carpio haematopterus }\end{array}$ & $\begin{array}{l}\text { Koi herpes virus } \\
\text { disease }\end{array}$ & {$[27]$} \\
\hline 15. & $\begin{array}{l}\text { Biofilm and free-cell vaccines of } \\
\text { Aeromonas hydrophila }\end{array}$ & $\begin{array}{c}\text { Indian large carp } \\
\text { Catlocarpio siamensis }\end{array}$ & Dropsy & {$[28$} \\
\hline 16. & $\begin{array}{l}\text { Streptococcus agalactiae (group B) } \\
\text { vaccine }\end{array}$ & $\begin{array}{c}\text { Tilapia } \\
\text { Cyphotilapia frontsa }\end{array}$ & Streptococcosis & [29] \\
\hline 17. & Betanodavirus & $\begin{array}{c}\text { Perch } \\
\text { Perca fluviatilis }\end{array}$ & Betanodavirus disease & {$[29]$} \\
\hline 18. & Enteric Redmouth (ERM) vaccine & $\begin{array}{l}\text { Salmon } \\
\text { S. salar }\end{array}$ & $\begin{array}{l}\text { Intestinal diseases red } \\
\text { mouth }\end{array}$ & {$[30]$} \\
\hline 19. & Pasteurella vaccine & $\begin{array}{l}\text { Salmon } \\
\text { S. salar }\end{array}$ & Pasteurellosis & {$[31]$} \\
\hline 20. & Aeromonas hydrophila vaccine & $\begin{array}{l}\text { Salmon } \\
\text { S. salar }\end{array}$ & $\begin{array}{l}\text { Motile septicemia } \\
\text { Aeromonas }\end{array}$ & {$[32]$} \\
\hline 21. & Carp Erythrodermatitis & $\begin{array}{c}\text { Carp } \\
\text { C. carpio }\end{array}$ & Erythrodermatitis & [33] \\
\hline 22. & Piscirickettsia salmonis vaccine & $\begin{array}{l}\text { Salmon } \\
\text { S. salar }\end{array}$ & Piskiriketsiosis & {$[33]$} \\
\hline 23. & Gaffkaemia vaccine & $\begin{array}{c}\text { Lobster } \\
\text { Homarus gammarus }\end{array}$ & Gaffkemia & {$[34]$} \\
\hline 24. & Nodavirus vaccine & $\begin{array}{c}\text { Seabass } \\
\text { Seabastes marinus }\end{array}$ & Viral necrosis & {$[35]$} \\
\hline 25. & Pancreas disease virus vaccine & $\begin{array}{l}\text { Salmon } \\
\text { S. salar }\end{array}$ & $\begin{array}{l}\text { Diseases of the } \\
\text { pancreas }\end{array}$ & {$[36]$} \\
\hline
\end{tabular}

In the recent years, the research into genetically engineered Pisces vaccines has made great progress. However, in the process of procedures for their application, the development and distribution of genetically modified Pisces vaccines also faces a number of problems that require solutions.

Some of the genetically modified Pisces vaccines developed in the 1990s have been practically proven in aquaculture with enormous economic and social benefits. Over the past 
decade, in «big ten» countries such as China and Japan, the development and production of genetically modified Pisces vaccines has evolved as a full-fledged industrial system. In China, a genetically modified vaccine has been developed and introduced against the hemorrhagic disease of herbivorous fish - grass carp Ctenophaaryngodon idello. It is a large herbivorous freshwater fish species of the family Cyprinidae native to eastern Asia, with an original range from northern Vietnam to the Amur River on the Siberia-China border, and very perspective object of commercial aquaculture.

Professionals - immunologists, genetics and vaccinologists - are now working closely to combine basic science with applied science and management, creating the prerequisites for the development of new effective Pisces vaccines. The inter-discipliunary research in recent years has shown that live vaccines also have great potential, and future research will also focus on the development of live vaccines. Analysis of molecular function and structure has contributed to the development of molecular vaccines. Thus, there are many methods and approaches for preparing an innovative Pisces vaccine, but different types of vaccines have in fact the same immune principles.

Chinese and Russian experts propose the following approaches to solving the problems of aquaculture and fisheries, which are connected with the distribution of infections.

(1) Research on the comprehensive development of marine resources, vigorous promotion of highly efficient and intensive aquaculture and «environmentally friendly» methods of cultivation, expansion of research in the field of technologies for obtaining high quality fish products, the formation of an optimal aquatic environment for fishing and fish farming, prevention of diseases of aquaculture facilities, quality improvement feed for cultured fish.

(2) Search and implementation of new innovative engineering technologies focused on the development of deep sea areas; removal of mariculture outside the coastal zone.

(3) Optimization of the structure of production, provision of high-quality aquatic products to domestic and foreign markets and meeting the needs of the population in improving the standard of living - including, first of all, increasing the income of fish farmers.

(4) Promote a sustainable aquaculture model, strengthen the management of the aquaculture industry, prudently plan the location and activities of aquaculture, strengthen the supervision and management of the introduction, production and use of planting material, feed, pharmaceuticals. Finding resources to support the healthy development of the aquaculture industry.

(5) Combining the cultivation of traditional objects with the search for new promising species that meet the needs of the market.

(6) Development of antibacterial and antiviral Pisces vaccines to protect the health of cultured fish. Expansion of work on the development and implementation of «DNAvaccines» to prevent water pollution, protect the environment and human health.

\section{References}

1. M.B. Shilin, D.A. Golubev, A.P. Alekseev, Pribrezhnaya akvakul'tura, 287 (SPb, izdvo RGGMU, 2009) (in Russian)

2. L. East, C.M. Isacke, Biochim Biophys Acta, 1572, 364-386 (2002)

3. A. Zlotnik, O. Yoshie, Immunity 36, 705-716 (2012)

4. R. Gudding, A. Lillehaug, Y. Evensen, Fish Vaccination, 341-351 (2014)

5. S. Lotti, N. Singh, M. Golding, M.B. Wheeler, L. Bertolini, C. Long, Transgenic Research 25 (1), 101-122 (2016) 
6. P. Papadopoulos, E. Tzironi, Journal of the Hellenic Veterinary Medical Society 59 (4), 308-319 (2017)

7. M.H. Iversen, R.A. Martin, Fish Physiology \& Biochemistry 40, 527-538 (2014)

8. M. Rozas, R. Ennquez, Journal of Fish Diseases 37, 163-188 (2014)

9. J.R. Winton, Journal of Applied Ichthyology 14, 153-158 (2010)

10. A. Kordon, H. Abdelhamed, W.A. Baumgartner, A. Karsi, L.M. Pinchuk, Fish \& Shellfish Immunology 53, 58-93 (2016)

11. S. Nuryati, Y. Alimuddin, Jurnal Akuakultur Indonesia 12 (2), 150-157 (2015)

12. D. Chen, Y. Yao, Z. Cui, X. Zhang, K. Peng, X. Guo, Y. Zhou, S. Li, N. Wu, Y. Zhang, Fish Shellfish Immunol 75, 66-73 (2018)

13. R.E. Wolfenden, S.L. Layton, A.D. Wolfenden, A. Khatiwara, B.M. Hargis, Poultry Science 89, 2370-2379 (2010)

14. B.O.L. Curieux, L. Vandelac, J. Caron, G.E. Seralini, Environmental Science \& Policy 12, 170-189 (2009)

15. A. Ayalew, A. Fufa, Veterinary Medicine International 2018, 1-10 (2018)

16. R. Antipa, D.F. Amend, Journal of the Fisheries Research Board of Canada 34, 203-208 (1977)

17. K. Salonius, C. Siderakis, A.M. Mackinnon, S.G. Griffiths, Developmental Biology 121, 189-197 (2005)

18. H.T. Boesen, K. Pedersen, J.L. Larsen, C. Koch, A.E. Ellis, Infection \& Immunity 67 (1), 294-301 (1999)

19. C. Mario, M. Carlos, M. Swetha, J. Larenas, J.A. Tobar, Fish \& Shellfish Immunology 54, 54-59 (2016)

20. M.F. Tatner, M.T. Horne, Aquaculture 46, 11-18 (1985)

21. E. Anderson, S. Clouthier, W. Shewmaker, A. Weighall, S. Lapatra, Journal of Fish Diseases 31, 729-745 (2010)

22. D.J. Wise, T.E. Greenway, T.S. Byars, M.J. Griffin, L.H. Khoo, Journal of Aquatic Animal Health, 27 (2), 135-143 (2015)

23. C.A. Shoemaker, P.H. Klesius, J.D. Drennan, J.J. Evans, Fish \& Shellfish Immunology 30, 304-308 (2011)

24. A. John Plumb, Somsak, W. Vinitnantharat, et al., Journal of Aquatic Animal Health 67 (1), 294-301 (1994)

25. A. John Plumb, Somsak, W. Vinitnantharat, et al., Journal of Aquatic Animal Health 67 (1), 294-301 (1994)

26. E.J. Emmenegger, G. Kurath, Vaccine 26, 6415-6421 (2008)

27. T. Miyazaki, Fish Pathology 40 (4), 201-207 (2009)

28. I. Azad, K. Shankar, C. Mohan, B. Kalita, Diseases of Aquatic Organisms 43, 103-108 (2000)

29. J.J. Evans, P.H. Klesius, C.A. Shoemaker, Vaccine 22, 3769-3773 (2004)

30. V.K. RoMer, N. Lukas, O. Maki, S.M.H. Kragelund, R.M. Kristian, M. Riccardo, Plos One 9 (4), e93845 (2014)

31. A.C. Barnes, N.M.S.D. Santos, A.E. Ellis, Developments in Biologicals, 121, 75-84 (2005) 
32. S. Poobalane, K.D. Thompson, L. Ardo, N. Verjan, H.J. Han, G. Jeney, I. Hirono, T. Aoki, A. Adams, Vaccine 28, 3540-3547 (2010)

33. D. Evenberg, P. Degraaff, B. Lugtenberg, Journal of Fish Diseases 11 (4), 337-350 (1988.)

34. J.E. Stewart, B.M. Zwicker, Journal of the Fisheries Research Board of Canada 31, 18871892 (1974)

35. S. Vimal, M.A. Farook, N. Madan, S.A. Majeed, A.S.S. Hameed, Aquaculture Research 47 (4), 1-12 (2016)

36. P.L. Skjold, I. Sommerset, P. Frost, S. Villoing, Veterinary Research 47, 78 (2016) 